\title{
ESTUDO BACTERIOLÓGICO DE ABSCESSOS CAUSADOS POR PICADA DE SERPENTES DO GENERO BOTHROPS.
}

\author{
João Guimarães de ANDRADE (1, 2), Raimundo Nonato L. PINTO (2), Ana Lúcia Sampaio Sgambatti de ANDRADE (1), \\ Celina Maria Turchi MARTELLI (1) \& Fábio ZICKER (1)
}

\begin{abstract}
RESUMO
Foi analisada a flora bacteriana de 99 abscessos causados por picadas de serpentes do gênero Bothrops, correspondendo a $61,1 \%$ dos casos que ocorreram em 1030 acidentes ofídicos atendidos no Hospital de Doenças Tropiciais (HDT) de Goiannia, no período de janeiro de 1984 a abril de 1988. O exsudato dos abscessos foi estudado através de bacterioscopia, cultura e testes de sensibilidade para aeróbios. Os bacilos Gram negativos foram isolados em maior frequencia, destacando-se a Morganella morganii, Escherichia coli e Providencia sp presentes respectivamente em $44,4 \%$. $20,2 \%$ e $13,1 \%$ das amostras. Esta flora aeróbica foi semelhante à encontrada na cavidade oral e no veneno das serpentes em outros estudos, nos quais predominaram Morganella morganii. Foi sugerido o uso do cloranfenicol no tratamento dos abscessos que nāo respondam à simples drenagem, face à grande sensibilidade destes microorganismos demonstrada nos testes "in vitro".
\end{abstract}

UNITERMOS: Bothrops; Acidente ofidico; Abscesso bacteriano.

\section{INTRODUÇÃO}

Os acidentes ofidicos representam um importante problema de saúde pública no país, não só por sua freqüència mas principalmente pelas complicações locais e sistêmicas que apresentam.

Embora sabendo-se que os ferimentos oca sionados por picadas de serpentes são potencial mente contaminados, predispondo à destruição tecidual e infecção bacteriana, a incidência e o papel desta infecçāo na patogênese das lesōes permanecem desconhecidos ${ }^{2.4 .6}$. As alteraçōes inflamatórias teciduais no local do ferimento causadas pelo veneno proteolítico dificultam a avaliação da presença de infecçāo secundária".

A maioria das publicaçōes sobre infecção em acidentes ofidicos tem analisado a flora bact $a$. riana da cavidade oral das serpentes e do veneno e a sua possivel correlação com os microorga nismos isolados nas lesōes. Uma ampla varie dade de bactérias aeróbicas e anaeróbicas tem sido isolada ${ }^{1,2,6.7,11}$. Uma flora bacteriana muito diversificada foi também observada em lesōes por Bothrops nos estudos realizados no Hospital Vital Brazil ${ }^{3.9}$.

(1) Instituto de Patologia Tropical e Saúde Pública, Universidade Federal de Goiás. Goiánia, Goiás. Brasil.

(2) Hospital de Doenças Tropicais de Goiania SUDS. Goiánia. Goias. Brasil

Endereço para correpondéncia: Dr. Joăo Guimaràes de Andrade. Rua 1136. n: 630, Setor Marista. CEP 74310 Goiánia. GO, Brasil. 
ANDRAde, J. G. de; PINTO, R. N. L.; ANDrade, A. L. S. S. de: MARTELli, C. M. T. \& ZICKER, F. - Estudo bacteriologico de abscessos causados por picada de serpentes do genero Bothrops. Rev. Inst. Med. trop. S. Paulo. 31(6):363-367. 1989

Este trabalho teve como objetivo analisar a flora bacteriana de abcessos provocados por picadas de serpentes do gênero Bothrops, e a sua sensibilidade aos agentes antimicrobianos.

\section{MATERIAL E MÉTODOS}

\section{Material de estudo}

Este estudo foi realizado no Hospital de Doenças Tropicais (HDT) de Goiânia, Centro de Referência Regional - Centro Oeste para aciden tes ofídicos, durante o período de janeiro de 1984 a abril de 1988 onde foram atendidos 1030 pacientes vitimas de acidente por serpentes do gênero Bothrops. O diagnóstico de acidente botrópico foi realizado utilizando-se parâmetros clínicos, a descrição da serpente, ou, mais raramente, a sua identificação quando trazida pelo paciente.

Cento e sessenta e dois $(15,7 \%)$ pacientes evoluiram com formação de abscesso no local da picada, caracterizado pela presença de lesão individualizada, flutuante, apresentando secre çào purulenta ou sero-purulenta no momento da internação ou no transcorrer da mesma.

Foi colhido material para bacteriologia de apenas um abscesso por paciente, sendo excluí dos 11 pacientes que fizeram uso profilático de antibiótico. Em 52 pacientes nāo foi possível coletar material das lesōes. Foram estudadas, portanto, 99 amostras, $61,1 \%$ do total dos casos com abscesso.

\section{Exame Bacteriológico}

A secreção dos abscessos foi coletada por aspiraçảo através de agulha ou por "zaragatoa" no momento da drenagem (espontânea ou nāo). O material foi enviado para o Laboratório de Saúde Pública - SUDS para exame bacterios cópico pelo método de Gram e cultura para aeró bios e microaerófilos. Nào foi realizada cultura para anaeróbios. O material foi semeado em Thioglicolato e incubado a $37^{\circ} \mathrm{C}$ por $24 \mathrm{hs}$. As colonias detectadas foram examinadas através do Gram e semeadas posteriormente em meio de Mac Conkey para bastonetes Gram negativos ou, Manitol e em ágar sangue, para cocos Gram positivos. Após incubação à $37^{\circ} \mathrm{C}$ por $24 \mathrm{hs}$, procedeu-se à identificação bioquimica utilizando- se os meios de IAL, caldo $\mathrm{MH}$ ou ágar $\mathrm{MH}$ por $24 \mathrm{hs}$ à $37^{\circ} \mathrm{C}$, de acordo com a bactéria isolada. Após a identificação da bactéria foi realizado tes te de sensibilidade aos antimicrobianos segundo a técnica de Kirby-Bauer (ágar Müller-Hinton). Ogerme foi considerado sensivel (S) ao medicamen to quando ocorreu halo de inibiçāo do seu cresci mento igual ou maior que $15 \mathrm{~mm}$ de diâmetro e resistente ( $R$ ) quando apresentou halo igual ou menor que $14 \mathrm{~mm}$.

\section{Análise dos dados}

Foram calculadas as freqüências de infecção por espécie bacteriana, utilizando-se como nu merador, o número de isolamentos de cada mi croorganismo e como denominador, o total de pacientes com abscesso.

Foram calculados coeficientes de sensibili dade bacteriana por antibiótico como o percen tual de testes com resultados sensiveis ao antimicrobiano específico no total de testes realizados com a espécie bacteriana em questāo.

\section{RESULTADOS}

Em $70(70,7 \%)$ casos houve isolamento de apenas uma espécie bacteriana, em $24(24,2 \%)$ foram isoladas duas e nos demais pacientes isolaram-se três ou mais espécies de bactérias. Em $28(28,2 \%)$ casos nāo houve correspondência entre as bactérias identificadas pelo Gram e o crescimento observado em cultura.

Os bacilos Gram negativos aeróbicos foram os mais frequentes, destacando-se a Morganella morganii, isolada em $44,4 \%$ das culturas, a Escherichia coli em $20,2 \%$ e a Providencia sp em $13,1 \%$. Observou-se uma pequena freqüencia de isolamento de Staphylococcus aureus $(8,1 \%)$ ( Tabela 1 ).

A maioria dos microorganismos isolados apresentou grande sensibilidade aos aminogli. cosideos, especialmente à amicacina e gentamicina. Observou-se também grande sensibilidade das bactérias isoladas ao cloranfenicol e à associaçāo sulfametoxazol-trimetoprim. A Morganella morganii, principal patógeno isolado, apresentou $95 \%$ de sensibilidade à gentamicina e amicacina, $92 \%$ ao cloranfenicol e $91 \%$ à sulfame- 
ANDRADE, J. G. de: PINTO. R. N. L.; ANDRADE. A. L. S. S. de: MARTELLI, C. M. T. \& ZICKER, F, - Fstudo bacteriológico de abscessos causados por picada de serpentes do genero Bothrops. Rev. Inst. Med. trop. S. Paulo. $31(6): 363-367,1989$

TABELA 1

Flora bacteriana encontrada em 99 abscessos por acidente botrópico.

\begin{tabular}{lcc}
\hline \multicolumn{1}{c}{ Bacterias } & N. de Isolamentos \\
\cline { 2 - 3 } & & N \\
\hline Morganella morganii & 44 & 44,4 \\
Escherichia coli & 20 & 20,2 \\
Providencia sp & 13 & 13,1 \\
Klebsiella sp & 10 & 10,1 \\
Alkaligenes sp & 09 & 9,1 \\
Enterobacter sp & 08 & 8,1 \\
Staphylococcus aureus & 08 & 8,1 \\
Staphylococcus epidermidis & 07 & 7,1 \\
Proteus mirabilis & 03 & 3,0 \\
Proteus vulgaris & 02 & 2,0 \\
Alkalescens sp & 02 & 2,0 \\
Citrobacter sp & 01 & 1,0 \\
Enterobacter aglomerans & 01 & 1,0 \\
Proteus rettgeri & 01 & 1,0 \\
Pseudomonas sp & 01 & 1,0 \\
\hline
\end{tabular}

toxazol-trimetoprim. Por outro lado, o Staphylococcus (aureus e epidermidis) apresentou pequena sensibilidade a quase todos os antimicro bianos testado, com exceção dos aminoglicosídeos e carbenicilina (Tabela 2).

\section{DISCUSSÃO}

Embora não se tenha estimativa da incidên cia de infecção bacteriana no ferimento dos aci dentes ofídicos, a sua ocorrência não parece ser tâo baixa como tem sido sugerido na literatura ${ }^{2}$ 4. 5. Nossos resultados em acidente botrópico mostram uma freqüencia de abscesso bacteria no em $15,7 \%$ dos casos, sugerindo que essa ocor réncia provavelmente depende do género da ser pente considerado.

No nosso material os bacilos Gram negativos foram identificados na maioria dos abscessos e a Morganella morganii foi o agente etiológico mais frequentemente isolado, ocorrendo em $44,4 \%$ dos casos. Estes resultados concordam com outros trabalhos onde os bacilos Gram negativos especialmente a Morganella morganii foram os agentes etiológicos isolados com maior frequên$\mathrm{cia}^{3}$. Entretanto, o $\mathbf{S}$. aureus e $\mathbf{S}$. fecalis foram as bactérias mais frequentes isoladas em $57 \%$ das lesōes por picadas de serpentes do gênero Bothrops em um estudo realizado em 14 pacientes no Hospital Vital Brazil ${ }^{9}$. Esta diferença talvez possa ser explicada pelo método de coleta empregado, pois neste último trabalho a cultura foi realizada com material de biópsia e de pun çāo. O S. aureus isolado poderia ser um contami nante ambiental ou da pele do paciente, nāo ne cessariamente implicado na patogênese do pro cesso infeccioso.

O espectro da flora aeróbica dos abscessos descrita em nosso estudo foi semelhante àquele que tem sido encontrado na cavidade oral e no

TABELA 2 - Coeficientes* de sensibilidade das principais bacterias isoladas de 99 abscessos por acidente botrópico

\begin{tabular}{|c|c|c|c|c|c|c|c|}
\hline \multirow[b]{2}{*}{ Antimicrobiano } & \multicolumn{7}{|c|}{ Microorganismos } \\
\hline & $\begin{array}{l}\text { Alkali- } \\
\text { genes sp }\end{array}$ & $\begin{array}{c}\text { Entero- } \\
\text { bacter sp }\end{array}$ & E. coli & $\begin{array}{c}\text { Klebsiella } \\
\text { sp }\end{array}$ & $\begin{array}{c}\text { M. } \\
\text { morganii }\end{array}$ & $\begin{array}{c}\text { Provi- } \\
\text { dencia sp }\end{array}$ & S. aureus \\
\hline Amicacina & 449 & $87: 8$ & $94: 18$ & $100 / 10$ & $95 / 42$ & $100: 11$ & $71: 7$ \\
\hline Ampicilina & $12: 8$ & 128 & $0 / 18$ & 1109 & $38 / 42$ & $18: 11$ & $0: 8$ \\
\hline Carbenicilina & $66: 9$ & 258 & $16: 18$ & $20: 10$ & $88 / 43$ & $40: 10$ & $83: 6$ \\
\hline Clindamicina & 06 & $0 / 5$ & $0: 14$ & 008 & $5 / 36$ & 1208 & 176 \\
\hline Cloranfenicol & $33: 9$ & 758 & $84 / 19$ & 8809 & $92 / 41$ & $81: 11$ & $62: 8$ \\
\hline Eritromicina & $16: 6$ & 05 & $35: 14$ & 1109 & $11 / 36$ & 2209 & $37: 8$ \\
\hline Gentamicina & $88: 9$ & $87: 8$ & $90: 20$ & 10010 & $95: 44$ & $90 / 11$ & 878 \\
\hline Kanamicina & $87: 8$ & 628 & 8419 & 8809 & $85: 40$ & $70: 10$ & 628 \\
\hline Lincomicina & 066 & $0 / 5$ & 007 & 0.09 & $0 / 37$ & 008 & $33 \cdot 6$ \\
\hline Oxacilina & $0 \% 9$ & $0: 8$ & $0: 20$ & 009 & $5: 42$ & $0: 10$ & 628 \\
\hline Penicilina & $0 \% 9$ & 08 & $0: 20$ & $0 / 10$ & $7 / 44$ & $0 / 11$ & 0.8 \\
\hline Rifampicina & 06 & $20: 5$ & $26 / 15$ & $12 / 08$ & $47 / 38$ & 1208 & 676 \\
\hline $\begin{array}{l}\text { Sulf + } \\
\text { Trimetoprim }\end{array}$ & $50 / 6$ & 1005 & $33 / 15$ & $62: 08$ & $91 / 37$ & 100.09 & $83: 6$ \\
\hline Tetraciclina & 449 & 508 & $76: 17$ & $60 / 10$ & $78: 41$ & $81: 11$ & $50 \cdot 8$ \\
\hline Vancomicina & 0.6 & $0 / 5$ & $0 / 12$ & 0.09 & 336 & 2508 & 176 \\
\hline
\end{tabular}

\% de testes sensiveis ao antimicrobiano no destes realizados 
ANDRADE. J. G. de: PINTO. R. N. L.; ANDRADE. A. L. S. S. de: MARTELII, C. M. T. \& ZICKER, F. - Estudo bacteriologico de abscessos causados por picada de serpentes do genero Bothrops. Rev. Inst. Med. trop. S. Paulo,

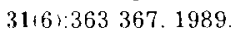

veneno das serpentes. Nestes estudos predominaram os Proteus sp (incluindo Morganella); os cocos Gram positivos, especialmente o $\mathbf{S}$. aureus foram raramente isolados 2.4 6.11. Em nosso estudo apesar da cultura para anaeróbios não ter sido realizada, a presença de rica bacterioscopia sem o correspondente crescimento bacteriano em cultura em quase $30 \%$ das amostras, pode sugerir a presença de anaeróbios. os quais tem sido identificados na flora da cavidade oral e no veneno de serpentes ${ }^{2.4 .11}$. Entretanto, não podemos descartar a possibilidade de que a flora isolada proceda do ambiente hospitalar ou da pele do próprio paciente.

O uso de antimicrobianos indicado empiri camente nos acidentes ofídicos tem sido uma constante ${ }^{4}$. 10. Nos acidentes botrópicos o uso de antibiótico com fins profiláticos e suposta mente terapêticos tem se constituido numa prática frequente no nosso meio. Entretanto, essa medida tem sido questionada, pois os sinais inflamatórios locais poderiam ser decorrentes da açảo do próprio veneno, sendo desnecessário o uso de antimicrobianos. A sua indicação deveria ficar restrita a situaçōes excepcionais onde exis. ta a possibilidade de infecçāo secundária. Esta hipótese deve ser considerada quando, pacien. tes corn quadro clínico já estabilizado, apresen tarem febre, enfartamento ganglionar regional e reativação dos sinais flogísticos locais. A dre. nagem simples dos abscessos tem sido suficiente para a resoluçảo do processo infeccioso $0^{8}$. A escoIha da droga deve levar em consideraçào a flora bacteriana e a sensibilidade destes agentes. A sensibilidade dos bacilos Gram negativos aos aminoglicosideos, ao cloranfenicol e à associa çāo sulfametoxazol-trimetoprim observada nes te trabalho foi também descrita ar.teriormente ${ }^{3}$.

Os resultados dos testes de sensibilidade realizados, e ainda a provável presença de anae róbios nos abscessos botrópicos em nosso estudo, nos permitem sugerir o uso do cloranfenicol no tratamento dos abscessos que nào respondam a simples drenagem. No entanto. ensaios clinicos aleatórios seriam necessários para ava liar a eficácia terapêutica dos antimicrobianos em abscessos botrópicos.

\section{SUMMARY}

\author{
Bacterial flora of abscesses following Bothrops \\ snakebite
}

The bacterial flora of 99 cases of abscesses following Bothrops snakebite were analysed They corresponded to $61.1 \%$ of all snakebite abs cesses observed in 1030 patients attending the Hospital de Doenças Tropicais de Goiania in Goiás, Brazil, from January 1984 to April 1988. An exsudate sample of each abscess was exami ned by Gram stain, culture and susceptibility tests. The Gram negative bacillis, Morganella morganii, Escherichia coli and Providencia sp were the most frequent bacterias isolated. They were identified in $44.4 \%, 20.2 \%$ and $13.1 \%$ of the samples respectively. This flora was similar to those described in snake mouth and venom by other researchers. Based on the results of the susceptibility tests the authors suggested the use of chloramphenicol for the treatment of tho se abscesses which do not respond to simple drainage.

\section{REFERENCIAS BIBLIOGRAFICAS}

1. GARCIA LIMA, E. \& LAURE, C. J. - A study of bacterial contamination of rattlesnake venom. Rev. Soc. bras. Med. trop., 20: 1921,1987

2. GOLDSTEIN. E. J. C.: CITRON, D. M.: GONZALEZ. H. RUSSEL. F. E. \& FINEGOLD. S. M. - Bacteriology of rattlesnake venom and implications for therapy. $J$. infect. Dis., 140: 818821,1979

3. JORGE, M. T.: RIBEIRO L. A.: SILVA. M. L. R.: KUSA NO. E. J. U. \& MENDONCA, J.S. - Bacteria isolated from abseess caused by Bothrops sp bites. In: INTERNA TIONAL CONGRESS FOR INFECTIOUS DISEASES V CONGRESSO DA SOCIEDADE BRASILEIRA DE IN FeCtologia, Rio de Janeiro, 1988. Programa e resumos. p.48, res. n: 671

4. LEDBETTER. E. O. \& KUTSCHER, A. E. - The acrobic and anaerobic flora of rattlesnake fangs a venom. Arch environm. Hith., 19: $770778,1969$.

5. MER RIAM .Ir. T. W. - Snakebite in Eastern North Caro lina. A review of 121 cases and Physician Survey. Report MR x 1, n: 3. Camp Lejeune, NC, US. Naval. Medical Field Research Laboratory, 1961.

6. PARRISH, H. M. - Incidence of treated snakebites in the United States. Publ. HIth. Rep., 81: 269276.1966

7. PARRISH. H. M. MACLAURIN, A. W. \& TUTTLE, R L. - North American pit vipers: bacterial flora of the mouths and venom glands. Virg. Med. Monthly, 83 $383385,1956$. 
ANDRADE, J. G. de: PINTO. R. N. L.: ANDRADE. A. L. S. S. de: MARTELli, C. M. T. \& ZiCkER. F. - Estudo bacteriológico de abscessos causados por picada de serpentes do genero Bothrops. Rev. Inst. Med. trop. S. Paulo, $31,6): 363-367,1989$

8. PINTO, R. N. L.: QUEIROZ. B. B. Q.; NALDANDIAR. H. A.: SOUZA, M. N.: SOUZA. L. C. S. \& ANDRADE. J. G. - Antibiótico como coadjuvante no tratamento de abs cessos por picada de serpentes do gênero Bothrops. Rev. Soc. bras. Med. trop., 21: 123.1988.

9. ROSA, R. R: LIZUKA. H.: HIGASHI, H. G.: CARDOSO J. L. C.: JORGE M. T. \& SILVA, M. V. - Isolamento de bacterias de lesoes provocadas por picadas de ofídios pe çonhentos. In: CONGRESSO DA SOCIEDADE BRASI
LEIRA DE MEDICINA TROPICAL. 19., Rio de Janeiro. 1983. Programa e resumos. p. 166, res. n: 380

10. RUSSEL. F. E. - Clinical aspects of snake ven poiso ning in North America. Toxicon, f: 33 37. 1969.

11. WILLIAMS, F. E.; FREEMAN, M. \& KENNEDY. E. The bacterial flora of the mouths of Australian venomous snakes in captivity. Med. J. Aust., 2: 190193,1954

Recebido para publieaçāo em 10031989 